\title{
Absence of sterols constrains food quality of cyanobacteria for an invasive freshwater bivalve
}

\author{
Timo Basen · Karl-Otto Rothhaupt • \\ Dominik Martin-Creuzburg
}

\begin{abstract}
The accumulation of cyanobacterial biomass may severely affect the performance of aquatic consumers. Here, we investigated the role of sterols in determining the food quality of cyanobacteria for the invasive clam Corbicula fluminea, which has become a common benthic invertebrate in many freshwater ecosystems throughout the world. In standardized growth experiments, juvenile clams were fed mixtures of different cyanobacteria (Anabaena variabilis, Aphanothece clathrata, Synechococcus elongatus) or sterol-containing eukaryotic algae (Cryptomonas sp., Nannochloropsis limnetica, Scenedesmus obliquus). In addition, the cyanobacterial food was supplemented with different sterols. We provide evidence that somatic growth of $C$. fluminea on cyanobacterial diets is constrained by the absence of sterols, as indicated by a growth-enhancing effect of sterol supplementation. Thus, our findings contribute to our understanding of the consequences of cyanobacterial mass developments for benthic consumers and highlight the importance of considering sterols as potentially limiting nutrients in aquatic food webs.
\end{abstract}

Keywords Benthic-pelagic coupling .

Corbicula fluminea - Cyanobacterial blooms .

Essential lipids - Food quality

Communicated by Ulrich Sommer.

T. Basen ( $\triangle)$ - K.-O. Rothhaupt - D. Martin-Creuzburg

Limnological Institute, University of Constance,

Mainaustrasse 252, 78464, Konstanz, Germany

e-mail: Timo.Basen@uni-konstanz.de

\section{Introduction}

The accumulation of cyanobacterial biomass, frequently observed in aquatic ecosystems around the globe, severely affects food web processes and is often associated with hazards to human health and livestock and reduced recreational quality of water bodies (Carmichael 1992; Codd 1995). As the frequency of cyanobacterial bloom formation is expected to increase with global warming (Paerl and Huisman 2008), it is important to investigate the consequences of cyanobacterial mass developments for ecosystem processes, e.g., the role of cyanobacterial carbon within the food web and its food quality for aquatic consumers.

In general, cyanobacteria represent a nutritionally inadequate food source for aquatic consumers, which is due to (1) morphological properties, i.e. to the formation of filaments or colonies that hamper ingestion (De Bernardi and Giussani 1990; Van Donk et al. 2011), (2) the production of toxins (Carmichael 1992; Wilson et al. 2006) or other secondary metabolites that reduce the efficiency of digestion (protease inhibitors; Schwarzenberger et al. 2010), and/or (3) a deficiency in essential biochemical nutrients, in particular sterols (Von Elert et al. 2003; Martin-Creuzburg et al. 2008). It is generally assumed that cyanobacteria, in contrast to eukaryotic algae, are unable to synthesize sterols de novo (Volkman 2003; Summons et al. 2006). Sterols are required for a multitude of physiological processes in eukaryotic consumers, e.g., they are indispensable structural components of cell membranes and serve as precursors for steroid hormones (Goad 1981; Martin-Creuzburg and Von Elert 2009). The lack of sterols has been suggested to constrain the carbon transfer efficiency from cyanobacteria to herbivorous zooplankton (Von Elert et al. 2003; MartinCreuzburg et al. 2008, 2010). 
When blooms settle down, a huge pelagic carbon pool is transferred to the benthic food web (Nascimento et al. 2008). It has been shown that cyanobacterial carbon can be ingested and assimilated by benthic invertebrates, but the nutritional value seems to be rather low (Karlson et al. 2008; Nascimento et al, 2009). In laboratory growth experiments, bivalves showed reduced growth and reproduction rates when fed cyanobacterial food sources (Wacker and von Elert 2003; Basen et al. 2011). Despite the fact that they are capable of removing colonial and filamentous cyanobacteria from the water column, feeding on cyanobacteria usually results in low ingestion rates and in an increased production of pseudofaeces, irrespective of cyanobacterial toxin production (Pires et al. 2005; Bontes et al. 2007). In contrast to morphological properties and toxicity, the role of essential dietary compounds in determining food quality for bivalve species has been poorly investigated. Experiments with marine bivalves, primarily species relevant for aquaculture, suggest that the ability to synthesize sterols de novo is generally low or absent (Walton and Pennock 1972; Goad 1981). Thus, a dietary source of sterols is presumably required for growth and reproduction (Soudant et al. 2000; Park et al. 2002), which may explain why cyanobacteria are of low nutritional quality for bivalve species.

One of the most spreading invaders in freshwater ecosystems is the Asian clam Corbicula fluminea. Originating in southeast Asia, C. fluminea has been introduced to North and South America and Europe in recent decades and has undergone a remarkable range expansion to become an ubiquitous benthic invertebrate in lentic and lotic freshwater ecosystems (McMahon 1982; Araujo et al. 1993; Darrigran 2002). Invasive bivalves, like $C$. fluminea and Dreissena polymorpha, can strongly affect invaded native ecosystems. As highly efficient filter feeders, they can alter phytoplankton dynamics, influence the pelagic nutrient cycling (Cahoon and Owen 1996; Hwang et al. 2011), and affect native benthic communities. By transferring pelagic carbon into the benthic food web, bivalves improve the benthic-pelagic coupling thereby stimulating benthic productivity (Strayer et al. 1999; Sousa et al. 2008; Gergs et al. 2009).

In the present study, we investigated the consequences of a dietary sterol deficiency for the growth of $C$. fluminea in standardized growth experiments. Juvenile clams were fed different sterol-free (cyanobacteria) and sterol-containing food sources (algae). In addition, clams were fed a mixture of three different cyanobacteria supplemented with sterols to assess whether the growth of $C$. fluminea on a cyanobacterial diet is constrained by a deficiency in dietary sterols. In addition, the sterol composition of food sources and clam tissues was recorded.

\section{Materials and methods}

Cultivation of cyanobacteria and algae

Food sources for $C$. fluminea were cultivated semi-continuously in aerated 5-1 vessels at a dilution rate of $0.25 \mathrm{day}^{-1}$ at $20^{\circ} \mathrm{C}$ with illumination at $100-120 \mu \mathrm{mol}$ quanta $\mathrm{m}^{-2} \mathrm{~s}^{-1}$, and harvested in the late-exponential growth phase. The coccoid cyanobacterium Synechococcus elongatus (SAG 89.70; Sammlung für Algenkulturen, Göttingen, Germany), the filamentous cyanobacterium Anabaena variabilis (ATCC 29413; American Type Culture Collection, Manassas, USA), the gelatinous cyanobacterium Aphanotece clathrata (SAG 23.99), the green alga Scenedesmus obliquus (SAG 276-3a) and the eustigmatophyte Nannochloropsis limnetica (SAG 18.99) were grown in Cyano medium (Jüttner et al. 1983). The flagellate Cryptomonas sp. (SAG 26.80) was grown in modified Woods Hole (WC) medium enriched with vitamins (Guillard 1975), nitrogen ( $2 \mathrm{mM}$, final concentration), and phosphorus $(100 \mu \mathrm{M}$, final concentration). These food organisms were used because they differ in their sterol content and composition. Food suspensions were prepared by concentrating the cells by centrifugation and resuspension in fresh media. Carbon concentrations of the food suspensions were estimated from photometric light extinctions $(800 \mathrm{~nm})$ and from carbon-extinction equations determined prior to the experiment.

\section{Sterol supplementation of cyanobacteria}

Cyanobacteria were enriched with a mixture of cholesterol (Sigma, C8667, purity 99\%), stigmasterol (Sigma, S2424, 95\%), and ergosterol (Sigma, E2000, 95\%) using a modified protocol of a method described by Von Elert (2002). Sterols were dissolved in ethanol $\left(2.5 \mathrm{mg} \mathrm{ml}^{-1}\right)$ to prepare ethanolic stock solutions. For supplementation, $40 \mathrm{mg}$ of bovine serum albumin (BSA, Sigma A7906, 98\%) was dissolved in $10 \mathrm{ml}$ of ultrapure water and $266.7 \mu \mathrm{l}$ of each sterol stock solution were added during gentle stirring. Subsequently, $10 \mathrm{ml}$ of Cyano medium and $2.67 \mathrm{mg}$ particulate organic carbon (POC) of the three cyanobacterial stock solutions ( $8 \mathrm{mg}$ POC in total) were added and, after $5 \mathrm{~min}$ of incubation, the volume was brought to $80 \mathrm{ml}$ with Cyano medium. The resulting suspension was incubated on a rotary shaker $(100 \mathrm{rpm})$ for $4 \mathrm{~h}$ with illumination at $100 \mu \mathrm{mol} \mathrm{m} \mathrm{m}^{-2} \mathrm{~s}^{-1}$. To remove excess BSA and free sterols, cyanobacterial cells were then concentrated by centrifugation and resuspended in fresh medium; this process was repeated twice. The obtained cyanobacterial food suspension ("Mix + BSA + Sterols") was then used as food for $C$. fluminea in the growth experiment. Control 
food suspensions ("Mix + BSA") were prepared similarly but without adding sterols.

\section{Clam sampling}

Corbicula fuminea were collected in February 2009 in the upper basin of Lake Constance at a sampling site described by Werner and Rothhaupt (2008). The clams were collected at a water depth of $2-3 \mathrm{~m}$ by scuba-diving. After separation of living individuals from debris, sand and gravel, they were placed in flow-through systems with filtered $(<30 \mu \mathrm{m})$, aerated lake water and pre-combusted sediment at an ambient temperature of $20^{\circ} \mathrm{C}$. Clams were kept under these conditions for 2 weeks until the start of the growth experiment.

\section{Growth experiments}

Adult bivalves invest most of their energy in reproduction (gametogenesis) and little in somatic growth (Soudant et al. 1999), therefore we used juveniles (initial dry mass 13.3$201.0 \mathrm{mg}$, including shells; size range $5-10 \mathrm{~mm}$ ) which were not sexually mature to maximize somatic growth rates. The 28-day experiment (24 February to 24 March 2009) was carried out at $20^{\circ} \mathrm{C}$. Glass beakers were filled with $200 \mathrm{ml}$ of filtered lake water $(0.45-\mu \mathrm{m}$ pore-sized membrane filter) and about $1 \mathrm{~cm}$ of precombusted sediment $\left(550^{\circ} \mathrm{C}\right.$ for $\left.5 \mathrm{~h}\right)$ to allow the clams to burrow. Clams were randomly transferred to each beaker. Each of the ten food treatments consisted of ten replicates, i.e. individual clams. Clams were fed daily with $3 \mathrm{mg} \mathrm{C}^{-1}$ of the food suspensions or starved without adding food. The experiment comprised the following food treatments: the three cyanobacteria $S$. elongatus, A. variabilis, and A. clathrata, the three eukaryotic algae $S$. obliquus, $N$. limnetica, and Cryptomonas sp., a mixture of the three cyanobacteria (1/3 POC provided by each species, "Mix"), either unsupplemented or supplemented with BSA (control, "Mix + BSA") or BSA and sterols ("Mix + BSA + Sterols"), and a mixture of the three eukaryotic algae. Water was exchanged daily to remove fecal pellets; sediment was exchanged once a week to reduce biofilm formation. Somatic growth rates $(g)$ were determined as the increase in total dry mass from the beginning of the experiment $\left(M_{0}\right)$ to day $28\left(M_{t}\right)$ over time $(t)$ using the equation:

$g=\frac{\left(\ln M_{t}-\ln M_{0}\right)}{t}$

A subsample of clams $(n=47)$ was taken at the beginning of the experiment to estimate the individual fresh and dry mass after $24 \mathrm{~h}$ of freeze-drying. Samples were weighed on an electronic balance (Mettler Toledo
$\mathrm{XP} 2 \mathrm{U} ; \pm 0.1 \mu \mathrm{g}$ ). The dry mass (DM, including shells) of clams at the start of each experiment was estimated from their actual fresh mass (FM, including shells) and previously established fresh-dry-mass regressions $\left(\mathrm{DM}=0.625 \mathrm{FM}, R^{2}=0.994\right)$. Growth rates of clams were calculated as means $(n=10) \pm$ standard deviation for each treatment $(n=10)$.

Analyses of food organisms and clam tissues

Aliquots of the food suspensions were filtered onto precombusted glass-fibre filters (Whatman GF/F, $25 \mathrm{~mm}$ diameter) and analyzed for particulate organic carbon (POC, $n=3$ per treatment) using an NCS-2500 analyzer (ThermoQuest). The carbon content of clams was determined by analyzing freeze-dried soft-body tissues dissected from subsampled individuals at the end of the experiment ( $n=3$ per treatment).

For the analysis of sterols, glass-fiber filters loaded with $\sim 1 \mathrm{mg}$ POC of the food suspensions ( $n=3$ ) were sonicated and stored at $-20^{\circ} \mathrm{C}$ in a mixture of dichloromethane/methanol $(2: 1, v / v)$. Soft-tissues of freeze-dried clams ( $n=3$ for each treatment) were separated from their shell, weighed, crushed by mechanical shearing using a mortar, sonicated, and subsequently stored at $-20^{\circ} \mathrm{C}$ in dichloromethane/methanol $(2: 1, \mathrm{v} / \mathrm{v})$. Total lipids of clam tissue or algae suspensions were extracted three times from each sample using dichloromethane/methanol $(2: 1, \mathrm{v} / \mathrm{v})$ and the pooled cell-free extracts were dried under a stream of nitrogen and saponified with $0.2 \mathrm{M}$ methanolic $\mathrm{KOH}$ $\left(70^{\circ} \mathrm{C}, 1 \mathrm{~h}\right)$. Subsequently, sterols were partitioned into isohexane:diethyl ether $(9: 1, v / v)$, dried under a stream of nitrogen, and resuspended in iso-hexane. Sterols were analyzed by gas chromatography (GC) on a HP 6890 GC (Agilent Technologies, Waldbronn, Germany) equipped with a flame ionization detector and a HP-5 (Agilent, $30 \mathrm{~m}$, $0.25 \mathrm{~mm}$ I.D., $0.25 \mu \mathrm{m}$ film) capillary column. Details of GC configurations are given elsewhere (Martin-Creuzburg et al. 2009). Sterols were quantified by comparison to an internal standard ( $5 \alpha$-cholestan). The detection limit was $20 \mathrm{ng}$ of sterol. Sterols were identified by their retention times and their mass spectra, which were recorded with a gas chromatograph-mass spectrometer (Finnigan MAT GCQ) equipped with a fused silica capillary column (DB5MS, Agilent, $30 \mathrm{~m}, 0.25 \mathrm{~mm}$ I.D., $0.25 \mu \mathrm{m}$ ). Sterols were analyzed in their free form and as their trimethylsilyl derivatives, which were prepared by incubating $20 \mathrm{ml}$ of iso-hexane sterol extract with $10 \mathrm{ml}$ of $\mathrm{N}, \mathrm{O}$-bis(trimethylsilyl)trifluoroacetamide including $1 \%$ trimethylchlorosilane for $1 \mathrm{~h}$ at room temperature. Mass spectra were recorded between 50 and 600 amu in the EI ionization mode. Sterols were identified by comparison with mass spectra of reference substances purchased from Sigma or Steraloids and/or 
mass spectra found in a self-generated spectra library or in the literature (e.g., Belanger et al. 1973; Goad and Akihisa 1997; Toyama et al. 1952). The C-24 stereochemistry and the cis-trans isomery of sterols could not be identified with certainty, and thus, if procurable, was adopted from the literature. The absolute amount of each sterol was related to the POC of the food sources or to the carbon content of clam soft-tissues and given as mean \pm standard deviation.

\section{Statistical analyses}

All statistical analyses were carried out using the statistical software package Statistica 6.0 (StatSoft). Differences among growth rates and among sterol levels in clam tissue were analyzed using one-way analyses of variance (ANOVA) and Tukey's HSD post hoc tests. The correlation between somatic growth rates of $C$. fluminea and sterol levels in clam tissue was assessed by linear regression analyses.

\section{Results}

Sterol composition of food sources

Sterols were not detected in cyanobacterial food suspensions, i.e. whether in A. variabilis, A. clathrata, or S. elongatus or in the unsupplemented or BSA-treated cyanobacterial food mixtures. When enriched with sterols, the cyanobacterial food mixtures contained on average $38.3 \pm 15.3 \mu \mathrm{g} \mathrm{mg} \mathrm{C}^{-1}$ of sterols in total, consisting of cholesterol (cholest-5-en-3 $\beta$ ol, $\left.\quad 13.5 \pm 3.9 \mu \mathrm{g} \mathrm{mg} \mathrm{C}^{-1}\right)$, ergosterol [(22E)-ergosta5,7,22-trien-3 $\beta$-ol, $\left.7.8 \pm 4.3 \mu \mathrm{g} \mathrm{mg} \mathrm{C}^{-1}\right]$, and stigmasterol [(22E)-stigmasta-5,22-dien-3 $\beta$-ol, $\left.17.1 \pm 7.4 \mu \mathrm{g} \mathrm{mg} \mathrm{C}^{-1}\right]$. The green alga $S$. obliquus contained on average $13.6 \pm 5.4 \mu \mathrm{g} \mathrm{mg} \mathrm{C}^{-1}$ of sterols in total, the principal sterols were fungisterol ( $5 \alpha$-ergost-7-en- $3 \beta$-ol, $4.6 \pm 1.8 \mu \mathrm{g}$ $\mathrm{mg} \mathrm{C}^{-1}$ ), chondrillasterol [(22E)-5 $\alpha$-poriferasta-7,22-dien$3 \beta$-ol, $7.8 \pm 3.4 \mu \mathrm{g} \mathrm{mg} \mathrm{C}^{-1}$ ], and 22-dihydrochondrillasterol ( $5 \alpha$-poriferast-7-en- $3 \beta$-ol, $1.1 \pm 0.2 \mu \mathrm{g} \mathrm{mg} \mathrm{C}^{-1}$ ). In Cryptomonas sp., total sterols averaged $8.4 \pm 4.2 \mu \mathrm{g} \mathrm{mg}$ $\mathrm{C}^{-1}$ and consisted of two principal sterols: brassicasterol [(22E)-ergosta-5,22-dien-3 $\beta$-ol, $\left.2.7 \pm 1.3 \mu \mathrm{g} \mathrm{mg} \mathrm{C}^{-1}\right]$ and stigmasterol $\left(5.7 \pm 2.9 \mu \mathrm{g} \mathrm{mg} \mathrm{C}^{-1}\right) . N$. limnetica contained $7.6 \pm 8.9 \mu \mathrm{g} \mathrm{mg} \mathrm{C}^{-1}$ of sterols in total, the principal sterols were cholesterol $\left(5.4 \pm 6.3 \mu \mathrm{g} \mathrm{mg} \mathrm{C}^{-1}\right.$ ), sitosterol (stigmast-5-en-3 $\beta$-ol, $1.2 \pm 1.4 \mu \mathrm{g} \mathrm{mg} \mathrm{C}^{-1}$ ), and fucosterol [(24E)-stigmasta-5,24(28)-dien-3 $\beta$-ol, $1.1 \pm 1.2 \mu \mathrm{g} \mathrm{mg}$ $\left.\mathrm{C}^{-1}\right]$.

Sterol composition of clam tissues

Six different sterols were identified in clam tissues: cholesterol $(40-72 \%$ of total sterols), brassicasterol (8-26\%), corbisterol [(22E)-stigmasta-5,7,22-trien-3 $\beta$-ol, 7-13\%], campesterol (campest-5-en-3 $\beta$-ol, 2-12\%), stigmasterol $(5-12 \%)$, and ergosterol $(0-5 \%)$ (Table 1). The total sterol content of field-collected clams at the start of the experiment was on average $9.8 \pm 2.1 \mu \mathrm{g} \mathrm{mg} \mathrm{C}^{-1}$. Lowest sterol concentrations were found in clams fed $A$. variabilis $\left(4.8 \pm 1.6 \mu \mathrm{g} \mathrm{mg} \mathrm{C}^{-1}\right)$ and highest levels were measured in clams fed $N$. limnetica $\left(12.9 \pm 5.0 \mu \mathrm{g} \mathrm{mg} \mathrm{C}^{-1}\right)$ and in clams fed sterol-supplemented cyanobacteria (12.6 \pm $0.6 \mu \mathrm{g} \mathrm{mg} \mathrm{C}^{-1}$ ). In general, total sterol levels of clams fed eukaryotic algae $\left(10.5 \pm 4.0 \mu \mathrm{g} \mathrm{mg} \mathrm{C}^{-1}, n=9\right)$ were significantly higher than those of clams fed cyanobacterial diets $\left(5.6 \pm 1.8 \mu \mathrm{g} \mathrm{mg} \mathrm{C}^{-1}, n=9\right.$, ANOVA, $F_{1,16}=$ 11.22, $P=0.004$, Fig. 1) and the total sterol content of clams fed sterol-supplemented cyanobacteria was significantly higher than those of clams fed unsupplemented or merely BSA-treated cyanobacteria (ANOVA, $F_{2,6}=$ 17.95, $P=0.003$; Tukey's HSD, $P<0.05$, Fig. 1).

\section{Growth of C. fluminea}

The dry mass of $C$. fluminea increased during the 28-day experiment in all food treatments, leading to positive somatic growth rates. In contrast, the dry mass of starving individuals slightly decreased during the experiment (Fig. 2). No clams died during the experiment. In general, clams fed one of the three cyanobacterial diets had lower growth rates than clams fed one of the three algal diets (ANOVA, $\quad F_{1,9}=19.44, \quad P<0.001$; Tukey's HSD, $P<0.05)$. Growth rates of clams fed the filamentous $A$. variabilis, the single-celled picocyanobacterium $S$. elongatus, the gelatinous A. clathrata or the unsupplemented or merely BSA-treated cyanobacterial diets (Mix, Mix + BSA) did not differ significantly (Tukey's HSD, $P>0.05$; Fig. 2). Likewise, the significantly higher growth rates obtained with the eukaryotic algae $S$. obliquus, $N$. limnetica and Cryptomonas sp. did not differ significantly from each other (Tukey's HSD, $P>0.05$ ). Growth rates of $C$. fluminea fed sterol-supplemented cyanobacterial food (Mix + BSA + Sterols) were significantly higher than those of clams fed unsupplemented cyanobacterial food (Mix, Mix + BSA), but did not differ from growth rates obtained with the eukaryotic food.

\section{Discussion}

Nutritional requirements of benthic invertebrates have been poorly studied, in particular with regard to essential biochemicals. We show here that somatic growth of the invasive freshwater clam $C$. fluminea on cyanobacterial diets is constrained by the absence of sterols, as indicated by a growth-enhancing effect of sterol supplementation. 


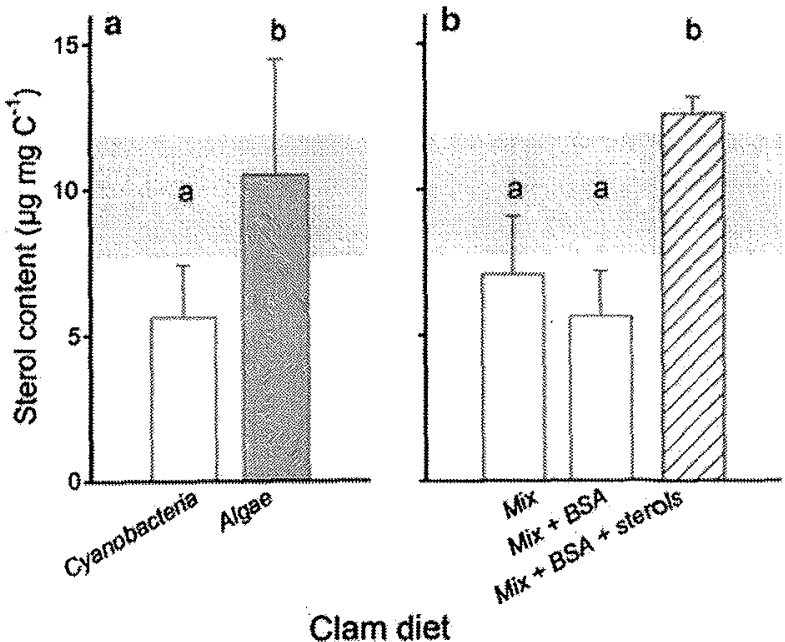

Fig. 1 a Sterol content of invasive clam Corbicula fluminea after 28 days of growth on a cyanobacterial diet (data obtained for the three cyanobacterial diets, Synechococcus elongatus, Anabaena variabilis, and Aphanotece clathrata combined, $n=9$ ) and on eukaryotic algae (data obtained for the three algal diets, Scenedesmus obliquus, Cryptomonas sp., and Nannochloropsis limnetica combined, $n=9$ ). b The sterol content of clams fed a mixture of all three cyanobacteria (Mix), a cyanobacterial mixture treated merely with bovine serum albumin $(M i x+B S A)$, or a cyanobacterial mixture treated with BSA and sterols (coarse bar, Mix $+B S A+$ Sterols) is shown for comparison $(n=3)$. The shaded background represents tissue sterol levels of clams at the beginning of the experiment. Data represent means and standard deviations (SD). Bars labeled with the same letters are not significantly different based on Tukey's HSD, $P<0.05$ following ANOVA; each panel represents a separate statistical analysis

This adds to previous findings showing that the growth of zooplankton (i.e. Daphnia) on cyanobacterial diets is constrained by the absence of sterols (Martin-Creuzburg et al. 2005, 2008) and thus highlights the importance of considering sterols as potentially limiting nutrients in aquatic food webs.

It has been suggested that the capability of synthesizing sterols de novo is low or even absent in bivalve species, which suggests that they rely on sufficient supply with dietary sterols to cover their physiological demands (Goad 1981; Napolitano et al. 1993; Soudant et al. 1996). Total sterol levels in the soft-body of clams fed the sterol-containing eukaryotic algae (Cryptomonas sp., N. limnetica or $S$. obliquus) were significantly higher than those of clams fed cyanobacterial diets, but did not differ from sterol levels determined in clams at the beginning of the experiment. In contrast, when grown on cyanobacterial diets, total sterol levels in clam tissues decreased compared to initial sterol levels. The supplementation of a cyanobacterial diet with sterols led to significantly increased sterol levels in clam soft-bodies, indicating an incorporation of 


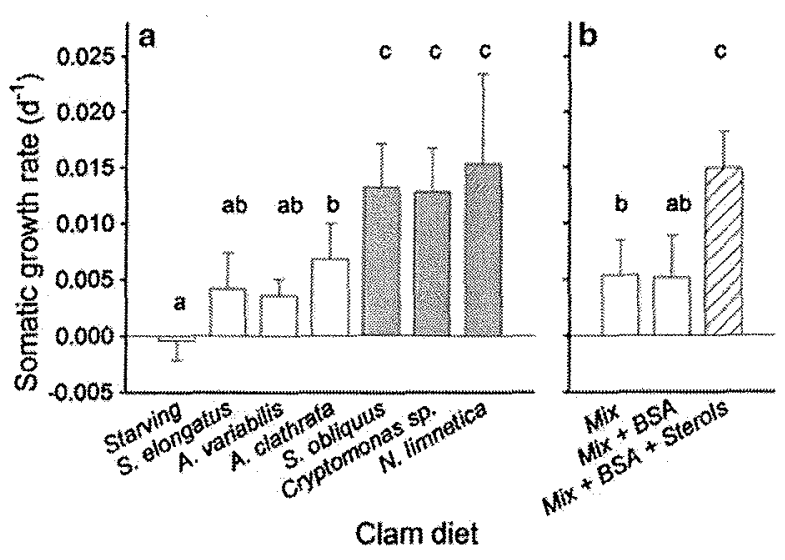

Fig. 2 Somatic growth rates of Corbicula fluminea a either starved or fed different cyanobacterial (Synechococcus elongatus, Anabaena variabilis, Aphanotece clathrata; white bars) or eukaryotic food sources (Scenedesmus obliquus, Cryptomonas sp., Nannochloropsis limnetica; gray bars). In addition, $\mathbf{b}$ growth rates of clams fed a mixture of all three cyanobacteria ( $\mathrm{Mix}$ ), a cyanobacterial mixture treated merely with bovine serum albumin $(M i x+B S A)$, or a cyanobacterial mixture treated with BSA and sterols (coarse bar $M i x+B S A+$ Sterols) are presented. Data are means $+\mathrm{SD}, n=10$ Bars labeled with the same letters are not significantly different based on Tukey's HSD, $P>0.05$ following ANOVA

supplemented sterols. In accordance with previous studies, the sterol composition of $C$. fiuminea was dominated by cholesterol, with lesser amounts of brassicasterol, campesterol, corbisterol, ergosterol, sitosterol, and stigmasterol (Duncan et al. 1987; Chijimatsu et al. 2011; Basen et al. 2011). Taking into account that bivalve species are presumably incapable of synthesising sterols de novo, sterols detected in soft-bodies of clams fed sterol-free cyanobacterial food were presumably incorporated and stored from dietary sources they had received prior to the experiment. The finding that sterols detected in clam tissues did not differ qualitatively, irrespective of the sterol composition of the food, suggests that C. fluminea is capable of converting dietary phytosterols to clam-specific sterols and that these sterols are functionally important in clam physiology. Besides sterols, long-chain polyunsaturated fatty acids (PUFAs) have been suggested to play an important role in bivalve nutrition (Soudant et al. 1996; Wacker et al. 2002; Basen et al. 2011). As both sterols and long-chain PUFAs are either absent or hardly represented in cyanobacteria, the growth of bivalves feeding on cyanobacteriadominated diets might be simultaneously constrained by the availability of dietary sterols and certain PUFAs, as has been shown in laboratory experiments with Daphnia (Martin-Creuzburg et al. 2009). Further detailed investigations on bivalve nutrition are needed to separate effects mediated by dietary sterols from those mediated by dietary PUFAs to assess the relative importance of these essential nutrients.
In many aquatic ecosystems throughout the world, the phytoplankton is, at least seasonally, dominated by cyanobacteria (Reynolds and Walsby 1975; Oliver and Ganf 2000). Climate scenarios with rising temperatures, increased atmospheric $\mathrm{CO}_{2}$ supplies and increased periods of thermal stratification are expected to favor cyanobacterial dominance (Jöhnk et al. 2008; Paerl and Huisman 2008), which may also affect trophic interactions in aquatic food webs as cyanobacteria are a nutritionally inadequate food source for most aquatic consumers (De Bernardi and Giussani 1990; Martin-Creuzburg et al. 2008). Recently, it has been stated that cyanobacterial carbon, deposited during bloom conditions in a marine system, did not support the benthic detritus-based food web (Karlson et al. 2008; Nascimento et al. 2009). Bivalves are significantly involved in transferring organic matter from pelagic sources to the sediment and thus provide a crucial link between pelagic and benthic food web processes (Newell 2004; Vaughn et al. 2008). Hence, it is important to understand the impact of cyanobacterial mass developments on bivalve species to more accurately assess consequences for benthic food web processes. Our data suggest that the benthicpelagic coupling between cyanobacteria and filter-feeding bivalves is at least partially constrained by a dietary sterol deficiency.

Corbicula fluminea is considered to be one of the most important invaders in aquatic ecosystems in the last decades (Araujo et al. 1993; McMahon 2000). In contrast to some other bivalves, which are able to sort food particles according to their size, shape or surface structure (Bontes et al. 2007; Espinosa et al. 2010), C. fluminea is regarded as a non-selective suspension feeder (Way et al. 1990; Vaughn and Hakenkamp 2001) and thus is presumably not able to discriminate against nutritionally inadequate food particles. It remains to be tested whether $C$. fluminea is able to adjust its feeding or assimilation rate in order to gain more of a limiting nutrient (i.e. compensatory feeding). Moreover, Corbicula might be able to change its feeding mode from seston filtration to deposition feeding via its muscular foot (Vaughn and Hakenkamp 2001; Nichols et al. 2005), and in this way may potentially avoid the uptake of nutritionally inadequate food sources present in the water column. Thus, the predominance of cyanobacterial carbon in the water column may result in an increased utilization of benthic food sources to overcome a possible sterol limitation. However, the availability of adequate benthic food sources is potentially scarce, in particular during cyanobacterial bloom condition, as significant amounts of cyanobacterial carbon are deposited to the sediment. Considering our data, this suggests that somatic growth of C. fluminea and potentially other filter-feeding bivalves is constrained by a deficiency in dietary sterols when cyanobacteria dominate the phytoplankton. Consequently, the 
expected increase in the frequency of cyanobacterial bloom formation in response to global warming may severely impair the growth of filter-feeding bivalves.

Acknowledgments We thank S. Oexle and $M$. Bauer for the support with the experiments, and $R$. Basen and three anonymous referees for helpful comments on the manuscript that improved its quality. This work was funded by the DFG (German Research Foundation) within the collaborative research centre CRC 454 "Littoral of Lake Constance".

\section{References}

Araujo R, Moreno D, Ramos MA (1993) The Asiatic clam Corbicula fuminea (Müller 1774) (Bivalvia, Corbiculidae) in Europe. Am Malacol Bull 10:39-49

Basen T, Martin-Creuzburg D, Rothhaupt K-O (2011) Role of essential lipids in determining food quality for the invasive freshwater clam Corbicula fluminea. J North Am Benthol Soc 30:653-664. doi:10.1899/10-087.1

Belanger P, Zintel JA, Vandenhe WJ, Smith JL (1973) Identification by combined gas-liquid chromatography-mass spectrometry of sterols isolated from Scenedesmus obliquus grown in light and heavy water. Can J Chem 51:3294-3298. doi:10.1139/v73-491

Bontes BM, Verschoor AM, Pires LMD, van Donk E, Ibelings BW (2007) Functional response of Anodonta anatina feeding on a green alga and four strains of cyanobacteria, differing in shape, size and toxicity. Hydrobiologia 584:191-204, doi:10.1007/ s10750-007-0580-2

Cahoon LB, Owen DA (1996) Can suspension feeding by bivalves regulate phytoplankton biomass in Lake Waccamaw, North Carolina? Hydrobiologia 325:193-200. doi:10.1007/BF000 14984

Carmichael WW (1992) Cyanobacteria secondary metabolites-the cyanotoxins. J Appl Bacteriol 72:445-459, doi:10.1111/j.13652672.1992.tb01858.x

Chijimatsu T, Umeki M, Okuda Y, Yamada K, Oda H, Mochizuki S (2011) The fat and protein fractions of freshwater clam (Corbicula fluminea) extract reduce serum cholesterol and enhance bile acid biosynthesis and sterol excretion in hypercholesterolaemic rats fed a high-cholesterol diet. $\mathrm{Br} \mathrm{J}$ Nutr 105:526-534. doi: $10.1017 / \$ 0007114510004058$

Codd GA (1995) Cyanobacterial toxins: occurrence, properties and biological significance. Water Sci Technol 32:149-156. doi: 10.1016/0273-1223(95)00692-3

Darrigran $G$ (2002) Potential impact of filter-feeding invaders on temperate inland freshwater environments. Biol Invasions 4:145-156. doi:10.1023/A:1020521811416

De Bernardi R, Giussani G (1990) Are blue-green algae a suitable food for zooplankton? An overview. Hydrobiologia 200:29-41

Duncan M, Fried B, Sherma J, Hoskin GP (1987) Lipids and sterols in Corbicula fluminea (Bivalvia). Comp Biochem Physiol B Biochem Mol Biol 87:881-883. doi:10.1016/0305-0491 (87) $90407-X$

Espinosa EP, Perrigault M, Ward JE, Shumway SE, Allam B (2010) Microalgal cell surface carbohydrates as recognition sites for particle sorting in suspension feeding bivalves. Biol Bull 218:75-86

Gergs R, Rinke K, Rothhaupt KO (2009) Zebra mussels mediate benthicpelagic coupling by biodeposition and changing detrital stoichiometry. Freshw Biol 54:1379-1391. doi:10.1111/j.1365-2427. 2009.02188.x
Goad LJ (1981) Sterol biosynthesis and metabolism in marine invertebrates. Pure Appl Chem 53:837-852. doi:10.1351/pac198 153040837

Goad LJ, Akihisa T (1997) Analysis of sterol. Blackie, London

Guillard RRL (1975) Cultures of phytoplankton for feeding of marine invertebrates. In: Smith WL, Chanley MH (eds) Culture of marine invertebrate animals. Plenum, New York, pp 29-60

Hwang SJ, Kim HS, Park JH, Kim BH (2011) Shift in nutrient and plankton community in eutrophic lake following introduction of a freshwater bivalve. J Environ Biol 32:227-234

Jöhnk KD, Huisman J, Sharples J, Sommeijer B, Visser PM, Stroom JM (2008) Summer heatwaves promote blooms of harmful cyanobacteria. Glob Change Biol 14:495-512. doi:10.1111/j.13652486.2007.01510.x

Jüttner F, Leonhardt J, Mohren $S$ (1983) Environmental factors affecting the formation of mesityloxide, dimethylallylic alcohol and other volatile compounds excreted by Anabaena cylindrica. J Gen Microbiol 129:407-412

Karlson AML, Nascimento FJA, Elmgren R (2008) Incorporation and burial of carbon from settling cyanobacterial blooms by depositfeeding macrofauna. Limnol Oceanogr 53:2754-2758. doi: 10.4319/lo.2008.53.6.2754

Martin-Creuzburg D, Von Elert E (2009) Ecological significance of sterols in aquatic food webs. In: Arts MT, Brett MT, Kainz MJ (eds) Lipids in aquatic ecosystems. Springer, New York, pp 43-64

Martin-Creuzburg D, Wacker A, von Elert E (2005) Life history consequences of sterol availability in the aquatic keystone species Daphnia. Oecologia 144:362-372. doi:10.1007/s00442005-0090-8

Martin-Creuzburg D, von Elert E, Hoffmann KH (2008) Nutritional constraints at the cyanobacteria-Daphnia magna interface: the role of sterols. Limnol Oceanogr 53:456-468. doi:10.4319/lo. 2008.53.2.0456

Martin-Creuzburg D, Sperfeld E, Wacker A (2009) Colimitation of a freshwater herbivore by sterols and polyunsaturated fatty acids. Proc R Soc Lond B 276:1805-1814. doi:10.1098/rspb.2008.1540

Martin-Creuzburg D, Wacker A, Basen T (2010) Interactions between limiting nutrients: consequences for somatic and population growth of Daphnia magna. Limnol Oceanogr 55:2597-2607. doi: $10.4319 / 10.2010 .55 .6 .2597$

McMahon RF (1982) The occurence and spread of the introducwed asiatic fresh-water clam, Corbicula fluminea (Müller), in NorthAmerica 1924-1982. Nautilus 96:134-141

McMahon RF (2000) Invasive charakteristics of freshwater bivalve Corbicula fluminea. In: Leach JH, Claudi R (eds) Nonidigenous freshwater organisms: vectors, biology and impacts. Lewis, Boca Raton

Napolitano GE, Ackman RG, Silvaserra MA (1993) Incorporation of dietary sterols by the sea scallop Placopecten magellanicus (Gmelin) fed on microalgae. Mar Biol 117:647-654. doi: 10.1007/bf00349777

Nascimento FJA, Karlson AML, Elmgren R (2008) Settling blooms of filamentous cyanobacteria as food for meiofauna assemblages. Limnol Oceanogr 53:2636-2643. doi:10.4319/1o.2008.53.6.2636

Nascimento FJA, Karlson AML, Naslund J, Gorokhova E (2009) Settling cyanobacterial blooms do not improve growth conditions for soft botton meiofauna. J Exp Mar Biol Ecol 368:138-146. doi:10.1016/j.jembe.2008.09.014

Newell RIE (2004) Ecosystem influences of natural and cultivated populations of suspension-feeding bivalve molluscs: a review. J Shellfish Res 23:51-61

Nichols SJ, Silverman H, Dietz TH, Lynn JW, Garling DL (2005) Pathways of food uptake in native (Unionidae) and introduced (Corbiculidae and Dreissenidae) freshwater bivalves. J Great Lakes Res 31:87-96 
Oliver RL, Ganf GG (2000) Freshwater blooms. In: Whitton BA Potts M (eds) The ecology of cyanobacteria. Kluwer, Netherlands, pp 149-194

Paerl HW, Huisman $\mathbf{J}$ (2008) Climate-blooms like it hot. Science 320:57-58. doi: $10.1126 /$ science. 1155398

Park DW, Jo QT, Lim HJ, Veron B (2002) Sterol composition of dark-grown Isochrysis galbana and its implication in the seed production of Pacific oyster, Crassostrea gigas. J Appl Phycol 14:351-355

Pires LMD, Bontes BM, Van Donk E, lbelings BW (2005) Grazing on colonial and filamentous, toxic and non-toxic cyanobacteria by the zebra mussel Dreissena polymorpha. J Plankton Res 27:331-339. doi:10.1093/plankt/fbi008

Reynolds CS, Walsby AE (1975) Water-blooms. Biol Rev Camb Philos Soc 50:437. doi:10.1111/j.1469-185X.1975.tb01060.x

Schwarzenberger A, Zitt A, Kroth P, Mueller S, Von Elert E (2010) Gene expression and activity of digestive proteases in Daphnia: effects of cyanobacterial protease inhibitors. BMC Physiol 10:6. doi: 10.1186/1472-6793-10-6

Soudant P, Marty Y, Moal J, Robert R, Quere C, LeCoz JR, Samain JF (1996) Effect of food fatty acid and sterol quality on Pecten maximus gonad composition and reproduction process. Aquaculture 143:361-378. doi:10.1016/0044-8486(96)01276-8

Soudant P, Van Ryckeghem K, Marty Y, Moal J, Samain JF, Sorgeloos P (1999) Comparison of the lipid class and fatty acid composition between a reproductive cycle in nature and a standard hatchery conditioning of the Pacific Oyster Crassostrea gigas. Compar Biochem Physiol B Biochem Mol Biol 123:209-222. doi:10.1016/S0305-0491(99)00063-2

Soudant P, Sanles MV, Quere C, Le Coz JR, Marty Y, Moal J, Samain JF, Sorgeloos P (2000) The use of lipid emulsions for stero supplementation of spat of the Pacific oyster, Crassostrea gigas. Aquaculture 184:315-326. doi:10.1016/S0044-8486(99)00323-3

Sousa R, Antunes C, Guilhermino L (2008) Ecology of the invasive Asian clam Corbicula, fluminea (Müller 1774) in aquatic ecosystems: an overview. Annales de Limnologie Int J Limnol 44:85-94, doi:10.1051/limn:2008017

Strayer DL, Caraco NF, Cole JJ, Findlay S, Pace ML (1999) Transformation of freshwater ecosystems by bivalves-a case study of zebra mussels in the Hudson River. Bioscience 49:19-27. doi:10.2307/1313490

Summons RE, Bradley AS, Jahnke LL, Waldbauer JR (2006) Steroids, triterpenoids and molecular oxygen. Philos Trans $\mathrm{R}$ Soc B Biol Sci 361:951-968. doi:10.1098/rstb.2006.1837
Toyama Y, Kita M, Tanaka T (1952) Sterols and other unsaponifiable substances in the fats of shell fishes, Crustacea and Echinodermata. 10. Corbisterol. Bull Chem Soc Jpn 25:355-357. doi: $10.1246 / \mathrm{bcsj} .25 .355$

Van Donk E, Ianora A, Vos M (2011) Induced defences in marine and freshwater phytoplankton: a review. Hydrobiologia 668:3-19. doi: 10.1007/s10750-010-0395-4

Vaughn CC, Hakenkamp CC (2001) The functional role of burrowing bivalves in freshwater ecosystems. Freshw Biol 46: 1431-1446. doi: 10.1046/j.1365-2427.2001.00771.x

Vaughn CC, Nichols SJ, Spooner DE (2008) Community and foodweb ecology of freshwater mussels. J North Am Benthol Soc 27:409-423. doi:10.1899/07-058.1

Volkman JK (2003) Sterols in microorganisms. Appl Microbiol Biotechnol 60:495-506. doi:10.1007/s00253-002-1172-8

Von Elert E (2002) Determination of limiting polyunsaturated fatty acids in Daphnia galeata using a new method to enrich food algae with single fatty acids. Limnol Oceanogr 47:1764-1773

Von Elert E, Martin-Creuzburg D, Le Coz JR (2003) Absence of sterols constrains carbon transfer between cyanobacteria and a freshwater herbivore (Daphnia galeata). Proc R Soc Lond Series B Biol Sci 270:1209-1214. doi:10.1098/rspb.2003.2357

Wacker A, Von Elert E (2003) Food quality controls reproduction of the zebra mussel (Dreissena polymorpha). Oecologia 135:332-338. doi:10.1007/s00442-003-1208-5

Wacker A, Becher P, Von Elert E (2002) Food quality effects of unsaturated fatty acids on larvae of the zebra mussel Dreissena polymorpha. Limnol Oceanogr 47:1242-1248

Walton MJ, Pennock JF (1972) Some studies on biosynthesis of ubiqiunone, isoprenoid alcohols, squalene and sterols by marine invertebrates. Biochem J 127:471-479

Way CM, Hornbach DJ, Millerway CA, Payne BS, Miller AC (1990) Dynamics of filter feeding in Corbicula fuminea (Bivalvia, Corbiculidae). Can J Zool Revue Canadienne De Zoologie 68:115-120. doi: $10.1139 / 290-016$

Werner S, Rothhaupt K-O (2008) Mass mortality of the invasive bivalve Corbicula fluminea induced by a severe low-water event and associated low water temperatures. Hydrobiologia 613:143-150. doi:10.1007/s10750-008-9479-9

Wilson AE, Sarnelle O, Tillmanns AR (2006) Effects of cyanobacterial toxicity and morphology on the population. growth of freshwater zooplankton: meta-analyses of laboratory experiments. Limnol Oceanogr 51:1915-1924 